\title{
Erratum: Pixel-Based Machine Learning and Image Reconstitution for Dot-ELISA Pathogen Diagnosis in Biological Samples
}

Frontiers Production Office*

Frontiers Media SA, Lausanne, Switzerland

Keywords: dot-blot ELISA, machine learning, image analysis, serological assays, sensitivity and specificity, ROC curve, diagnostic performance

\section{An Erratum on}

Approved by:

Frontiers Editorial Office,

Frontiers Media SA, Switzerland

*Correspondence:

Frontiers Production Office production.office@frontiersin.org

Specialty section:

This article was submitted to

Microbial Immunology,

a section of the journa

Frontiers in Microbiology

Received: 31 March 2021

Accepted: 31 March 2021

Published: 27 April 2021

Citation:

Frontiers Production Office (2021)

Erratum: Pixel-Based Machine Learning and Image Reconstitution for

Dot-ELISA Pathogen Diagnosis in

Biological Samples.

Front. Microbiol. 12:688832.

doi: 10.3389/fmicb.2021.688832
Pixel-Based Machine Learning and Image Reconstitution for Dot-ELISA Pathogen Diagnosis in Biological Samples

by Anastassopoulou, C., Tsakris, A., Patrinos, G. P., and Manoussopoulos, Y. (2021). Front. Microbiol. 12:562199. doi: 10.3389/fmicb.2021.562199

Due to a production error, two formulas were incorrectly published in the Materials and Methods section, subsection Step 2: Model Selection and Supervised Training of the Classifier Algorithm. The correct formulas are provided below.

$$
\begin{array}{r}
\ln [\pi(x) / 1-\pi(x)]=\alpha+\beta_{1} x_{R}+\beta_{2} x_{G}+\beta_{3} x_{B}+\beta_{4} x_{D i l} \\
\pi(x)=\frac{e^{\alpha+\beta_{1} x_{R}+\beta_{2} x_{G}+\beta_{3} x_{B}+\beta_{4} x_{D i l}}}{1+e^{\alpha+\beta_{1} x_{R}+\beta_{2} x_{G}+\beta_{3} x_{B}+\beta_{4} x_{D i l}}}
\end{array}
$$

The publisher apologizes for this mistake. The original article has been updated.

Copyright $\odot 2021$ Frontiers Production Office. This is an open-access article distributed under the terms of the Creative Commons Attribution License (CC BY). The use, distribution or reproduction in other forums is permitted, provided the original author(s) and the copyright owner(s) are credited and that the original publication in this journal is cited, in accordance with accepted academic practice. No use, distribution or reproduction is permitted which does not comply with these terms. 